\section{Role of Aluminum Speciation in the Removal of Disinfection Byproduct Precursors by a Coagulation Process}

\author{
HE ZHAO, ${ }^{\dagger,}$ C $\mathrm{CHEGZHI} \mathrm{HU,}{ }^{\dagger}$ \\ H UIJUAN LIU, ${ }^{\dagger} \mathrm{XU} \mathrm{ZHAO}^{\dagger}{ }^{\dagger} \mathrm{AND}$ \\ J I U H I Q U*, ${ }^{*}$ \\ State Key Laboratory of Environmental Aquatic Chemistry, \\ Research Center for Eco-Environmental Sciences, Chinese \\ Academy of Sciences, Beijing 100085, China, and Graduate \\ School, Chinese Academy of Sciences, Beijing 100039, China
}

Received February 29, 2008. Revised manuscript received May 14, 2008. Accepted May 15, 2008.

Humic acid (HA) was extracted and separated into different molecular weight (MW) fractions, then coagulated by aluminum chloride and polyaluminum chloride (PACI). The removal of disinfection byproduct (DBP) precursors and the aluminum speciation variation of the coagulants were investigated in detail. In particular, the role of aluminum speciation in the removal of DBP precursors was discussed. During the coagulation process, $\mathrm{AlCl}_{3}$ hydrolyzed into dominating in situ $\mathrm{Al}_{13}$ species at $\mathrm{pH}$ 5.5. The in situ $\mathrm{Al}_{13}$ species exhibited better removal ability for haloacetic acid (HAA) precursors than PACl. At pH 7.5, in situ hydrolyzed $\mathrm{Al}_{13}$ species of $\mathrm{AlCl}_{3}$ decomposed into dimeric Al species. In this case, preformed $\mathrm{Al}_{13}$ of $\mathrm{PACl}$ had a high removal ability of HAA precursors. Specially, the greatest reduction of HAA precursors with a low MW $(<30 \mathrm{kDa})$ was through charge neutralization at $\mathrm{pH} 5.5$, and that of HAA precursors in high $\mathrm{MW}(>30 \mathrm{kDa})$ fractions was through adsorption at $\mathrm{pH}$ 7.5. Different from HAA precursors, the in situ $\mathrm{Al}_{13}$ species did not have a high removal ability of trihalomethane (THM) precursors. Therefore, $\mathrm{PACl}$ exhibited a better removal ability of THM precursors than $\mathrm{AICl}_{3}$ at different $\mathrm{pH}$ values. In the different MW fractions, the greatest reduction of THM precursors was through charge neutralization at pH 5.5 .

\section{Introduction}

Natural organic matter (NOM), which widely exists in raw water, can react with chlorine in water treatment processes to form halogenated disinfection byproduct (DBPs) (1). In particular, humic substances are the principal precursors of trihalomethanes (THMs) (2) and haloacetic acids (HAAs) (3).

Enhanced coagulation is an effective method for DBP precursor removal, especially for high MW organic compounds $(>30 \mathrm{kDa})(4-6)$. Aluminum chloride $\left(\mathrm{AlCl}_{3}\right)$ and polyaluminum chloride (PACl) are common coagulants for DBP precursor removal. Many researchers believe that $\mathrm{PACl}$ is superior to traditional aluminum coagulants in removing turbidity, dissolved organic carbon (DOC), and UV absorbance at $254 \mathrm{~nm}\left(\mathrm{UV}_{254}\right)(7,8)$. With the characteristics of

* Corresponding author phone: +86 106284 9151; fax: +86 10 6292 3558; e-mail: jhqu@rcees.ac.cn.

${ }^{\dagger}$ Research Center for Eco-Environmental Sciences.

‡ Graduate School. high positive charge and strong binding ability, preformed Keggin- $\mathrm{Al}_{13}\left(\mathrm{~K}_{-} \mathrm{Al}_{13}, \mathrm{AlO}_{4} \mathrm{Al}_{12}(\mathrm{OH})_{24}\left(\mathrm{H}_{2} \mathrm{O}\right)_{12}{ }^{7+}\right.$ ) (9) compounds were claimed as the most active species responsible for coagulation. These special aluminum species contributed to the superior behavior of PACl in coagulation (10).

Previous investigations (11) demonstrated that traditional aluminum salts $\left(\mathrm{AlCl}_{3}\right)$ generated in situ polymeric species $\left(\mathrm{Al}_{b}\right)$ at $\mathrm{pH} 5.0-6.0$ in coagulation process. $\mathrm{AlCl}_{3}$ with a high content of in situ transformed $\mathrm{Al}_{b}$ species was more effective than $\mathrm{PACl}$ in removing DOC and $\mathrm{UV}_{254}$. However, although the influence of aluminum speciation on coagulation behavior has received much attention $(12,13)$, the role of aluminum speciation in DBP precursor removal has not been reported until now. As to whether $\mathrm{K}-\mathrm{Al}_{13}$ is the most active species responsible for DBP precursor removal still needs clarification. Furthermore, the variation of aluminum speciation variation of coagulants during the coagulation process also needs further investigation.

The primary objective of the present research was to determine the role of aluminum speciation in the removal of DBP precursors by Al-based coagulation. The removal trends of the two major DBP groups (THM or HAA formation potential per DOC, THMFP/DOC, or HAAFP/DOC) for different MW fractions of HA by coagulation with $\mathrm{PACl}$ and $\mathrm{AlCl}_{3}$ were studied in detail. In particular, aluminum speciation variation of coagulants during the coagulation process was investigated using electrospray ionization (ESI) mass spectrometry.

\section{Experimental Procedures}

HA and Fractionation. HA was extracted from the sediments of the Hanshiqiao wetland in Beijing, China. Extracted HA was dissolved in a $\mathrm{NaOH}$ solution and then filtered through $0.45 \mu \mathrm{m}$ cellulose acetate membrane filters and stored in the dark at $4^{\circ} \mathrm{C}$. Some information on the elemental composition and acidity of HA is shown in the Supporting Information.

Diluted HA (10 mg/L DOC) was fractionated into six fractions using a stirred ultrafiltration cell device (Model 8200 , Amicon, Millipore) with nominal molecular weight cutoffs of $3,10,30,100$, and $300 \mathrm{kDa}$ regenerated cellulose membranes (PL, $63.5 \mathrm{~mm}$, Millipore). Details are according to the procedure mentioned by Kitis et al. (14). The DOC and $\mathrm{UV}_{254}$ values of each HA fraction were measured.

Jar Tests. Each HA fraction was made to resemble the alkalinity, ionic strength, and turbidity levels of natural water, with a DOC concentration of $4.5 \pm 0.3 \mathrm{mg} / \mathrm{L}$ as $\mathrm{C}$. With a fixed coagulant dose ( $0.8 \mathrm{mg} \mathrm{Al} / \mathrm{mg}$ DOC), jar tests were in a pH range of 3.5-9.5. Details of jar tests are presented in the Supporting Information. After settling was complete, the collected supernatants were filtered through $0.45 \mu \mathrm{m}$ membrane filters for testing DOC, $\mathrm{UV}_{254}$, THMFP, and HAAFP.

DBP Formation Potential. Raw HA fractions and filtered water samples obtained from the jar tests were used in the chlorination procedure. Prior to the addition of chlorine, all water samples were adjusted to $\mathrm{pH} 7.0 \pm 0.2$. After dosing $20 \mathrm{mg} / \mathrm{L}$ chlorine, capped samples were in a $20^{\circ} \mathrm{C}$ incubator for $72 \mathrm{~h}$. All samples were found to have measurable free chlorine residuals by a $N, N$-diethyl- $p$-phenylenediamine (DPD) titrimetric method (15). THM and HAA samples were measured following U.S. EPA Methods 551 and 552.3 (16), respectively. Quantitative analysis was conducted using a gas chromatograph (6890N, Agilent) and an electron capture detector (ECD). Details of DBPFP tests are included in the Supporting Information.

Characterization of Aluminum Speciation of Coagulants. $\mathrm{AlCl}_{3} \cdot 6 \mathrm{H}_{2} \mathrm{O}$ (Guaranteed Reagent, Beijing Chemical 
TABLE 1. MW Distribution of HA by Ultrafiltration Fractionation

\begin{tabular}{|c|c|c|c|c|c|c|}
\hline & & $<3 \mathrm{kDa}$ & 3-10 kDa & $10-30 \mathrm{kDa}$ & $30-100 \mathrm{kDa}$ & $>100$ kDa \\
\hline & & & Before Coagul & & & \\
\hline DOC & & 6.85 & 11.51 & 23.07 & 30.22 & 28.35 \\
\hline $\mathrm{UV}_{25}$ & & 7.63 & 13.03 & 21.49 & 33.66 & 24.19 \\
\hline SUVA (L/ & $\mathrm{m})$ & 3.10 & 3.15 & 2.59 & 3.10 & 2.38 \\
\hline THMFP/DOC & (mg C) & $87.51( \pm 0.38)$ & $85.23( \pm 0.70)$ & $83.02( \pm 0.69)$ & $76.65( \pm 1.15)$ & $80.17( \pm 0.85)$ \\
\hline HAAFP/DOC & (mg C) & $28.13( \pm 1.20)$ & $25.01( \pm 0.57)$ & $21.35( \pm 0.38)$ & $19.49( \pm 0.71)$ & $18.68( \pm 1.06)$ \\
\hline & & & After Coagul & & & \\
\hline - $(m g / l)$ & pH 5.5 & 3.68 & 3.43 & 2.93 & 1.44 & 0.99 \\
\hline $\mathrm{DOC}(\mathrm{mg} / \mathrm{L})$ & $\mathrm{pH} 7.5$ & 3.20 & 2.87 & 2.26 & 0.83 & 0.85 \\
\hline $1 / V_{-r}(1 / \mathrm{cm})^{b}$ & $\mathrm{pH} 5.5$ & 0.063 & 0.039 & 0.020 & 0.019 & 0.011 \\
\hline$U V_{254}(1 / \mathrm{cm})^{\circ}$ & pH 7.5 & 0.099 & 0.054 & 0.019 & 0.014 & 0.015 \\
\hline
\end{tabular}

${ }^{a} \mathrm{DOC}$ recovery was $90.8 \%$ during fractionation. ${ }^{b} \mathrm{DOC}$ and $\mathrm{UV}_{254}$ values were from coagulation with $\mathrm{AICl}_{3}$.

Reagents Company) and $\mathrm{PACl}\left(81.2 \% \mathrm{~K}_{-} \mathrm{Al}_{13}\right.$, prepared using an electrolysis process (17)) were used for all jar tests. Characteristics of the coagulants used are presented in the Supporting Information.

To detect the aluminum speciation variation of $\mathrm{AlCl}_{3}$ using ESI measurements, $\mathrm{AlCl}_{3}$ was dissolved in deionized water to obtain a final solution of $1.5 \times 10^{-4} \mathrm{~mol} / \mathrm{L}$. Tetramethylammonium hydroxide pentahydrate $\left(\left(\mathrm{CH}_{3}\right)_{4} \mathrm{NOH} \cdot 5 \mathrm{H}_{2} \mathrm{O}\right.$ (TMA), Analytical Reagent, Beijing Chemical Reagents Company) or a $\mathrm{HCl}$ solution was added to the solution to control the $\mathrm{pH}$ (18). Then, the solution was injected into the mass spectrometer. ESI mass spectra were recorded with a micromass hybrid quadrupole time-of-flight (TOF) mass spectrometer (2695XE micro, Waters) equipped with an electrospray ion source. All ESI mass spectral data were obtained in positive ion mode. Details of the operating procedure are shown in the Supporting Information. Major ions in the ESI-MS spectra, which represent specific aluminum complexes, were selected for the ESI-MS/MS study.

\section{Results and Discussion}

Fractionation of HA. The MW distribution of HA by ultrafiltration fractionation is presented in Table 1. The $30-100,>100$, and $10-30 \mathrm{kDa}$ fractions were the three major components in HA, and the specific ultraviolet absorbances (SUVAs) of each fraction were close to each other. Table 1 also summarizes the THMFP and HAAFP specific yields of individual fractions before coagulation. Each fraction of HA had more THM precursors (76.65-87.51 $\mu \mathrm{g} / \mathrm{mg} \mathrm{C}$ ) than HAA precursors (18.68-28.13 $\mu \mathrm{g} / \mathrm{mg} \mathrm{C})$. The lowest MW $(<3 \mathrm{kDa})$ fraction produced the highest THMFP and HAAFP yields, whereas the $30-100$ and $>100 \mathrm{kDa}$ fractions produced the lowest THMFP and HAAFP yields, respectively. The general trend was that lower MW fractions had more reactive precursors for DBP formation.

Removal of DBP Precursors by Coagulation. Figures 1 and 2 illustrate the removal of THM and HAA precursors of $\mathrm{HA}$ fractions by coagulation with $\mathrm{AlCl}_{3}$ and $\mathrm{PAC}$, respectively. Images showing DBP removal at $\mathrm{pH} 9.5$ are presented in the Supporting Information.

As shown in Figure 1, PACl removed more THM precursors than $\mathrm{AlCl}_{3}$ at $\mathrm{pH} 3.5,5.5$, and 7.5. In the different $\mathrm{MW}$ fractions, the greatest removal of specific THMFP yields occurred at $\mathrm{pH}$ 5.5. The reduction of specific THMFP yields by coagulation with PACl was 48.0, 56.7, 55.9, 47.6, and $52.5 \mu \mathrm{g} / \mathrm{mg}$ DOC, respectively. The differences of THM precursor removal in different MW fractions by $\mathrm{PACl}$ coagulation at $\mathrm{pH} 5.5$ were not significant. The reduction of THM precursors by coagulation with $\mathrm{PACl}$ at $\mathrm{pH} 7.5$ was almost equal to that at $\mathrm{pH}$ 5.5 , except in the $3-10 \mathrm{kDa}$ fraction. At $\mathrm{pH} 7.5$, the reductions of specific THMFP yields in the $<3,3-10,10-30,30-100$, and $>100 \mathrm{kDa}$ fractions were 47.3, 42.2, 55.3, 46.9, and 52.1 $\mu \mathrm{g} / \mathrm{mg}$ DOC, respectively. As shown in Figure 1a, the THM

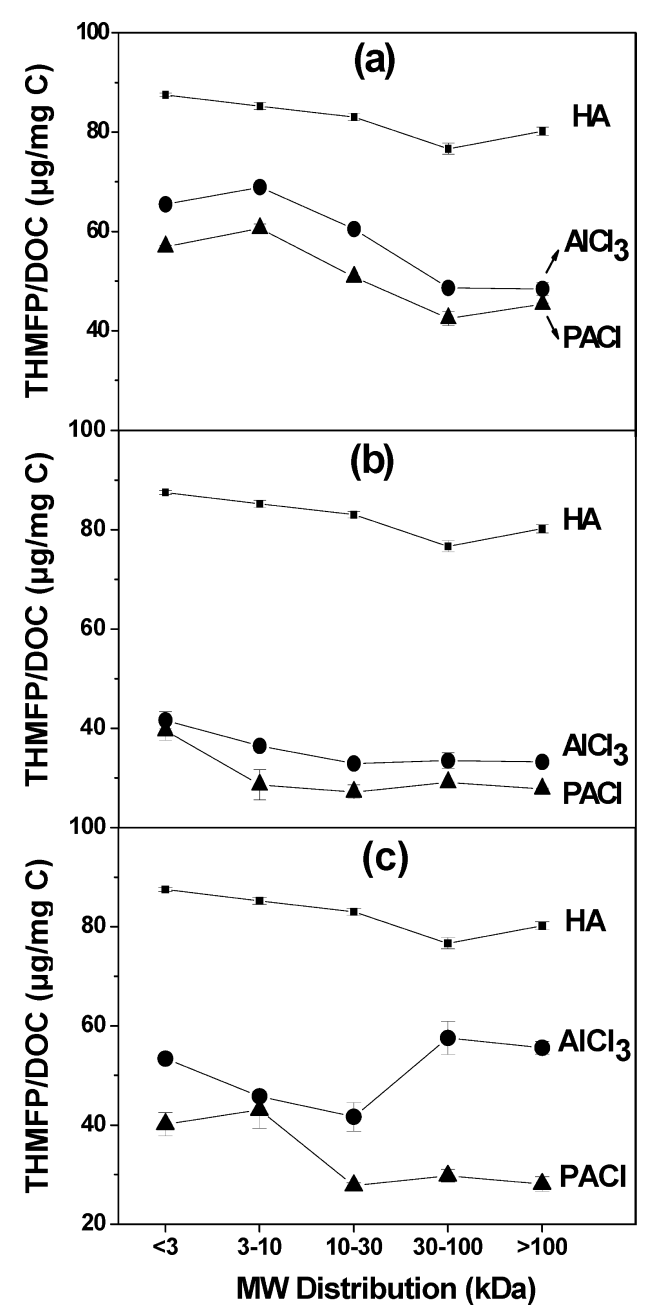

FIGURE 1. Specific THMFP yields of different MW fractions after coagulation with $\mathrm{AICl}_{3}$ and $\mathrm{PACl}$ (coagulants dose: $0.8 \mathrm{mg}$ Al/mg DOC): (a) pH 3.5, (b) pH 5.5, and (c) pH 7.5.

precursors with high MWs were removed more than the THM precursors with low MWs by $\mathrm{PACl}$ coagulation at $\mathrm{pH} 3.5$.

The ability of $\mathrm{AlCl}_{3}$ and $\mathrm{PACl}$ to remove THM precursors over a wide $\mathrm{pH}$ range was different. The differences between $\mathrm{AlCl}_{3}$ and PACl upon removal of THM precursors at $\mathrm{pH} 7.5$ were larger than that at other $\mathrm{pH}$ values, especially for the high MW (>30 kDa) fractions. At pH 7.5, the low MW THM precursors were removed more than the high MW THM precursors by $\mathrm{AlCl}_{3}$ coagulation. At $\mathrm{pH} 3.5$ and 5.5, the removal trends of THM precursors by $\mathrm{AlCl}_{3}$ coagulation paralleled the removal trends by $\mathrm{PACl}$ coagulation. 


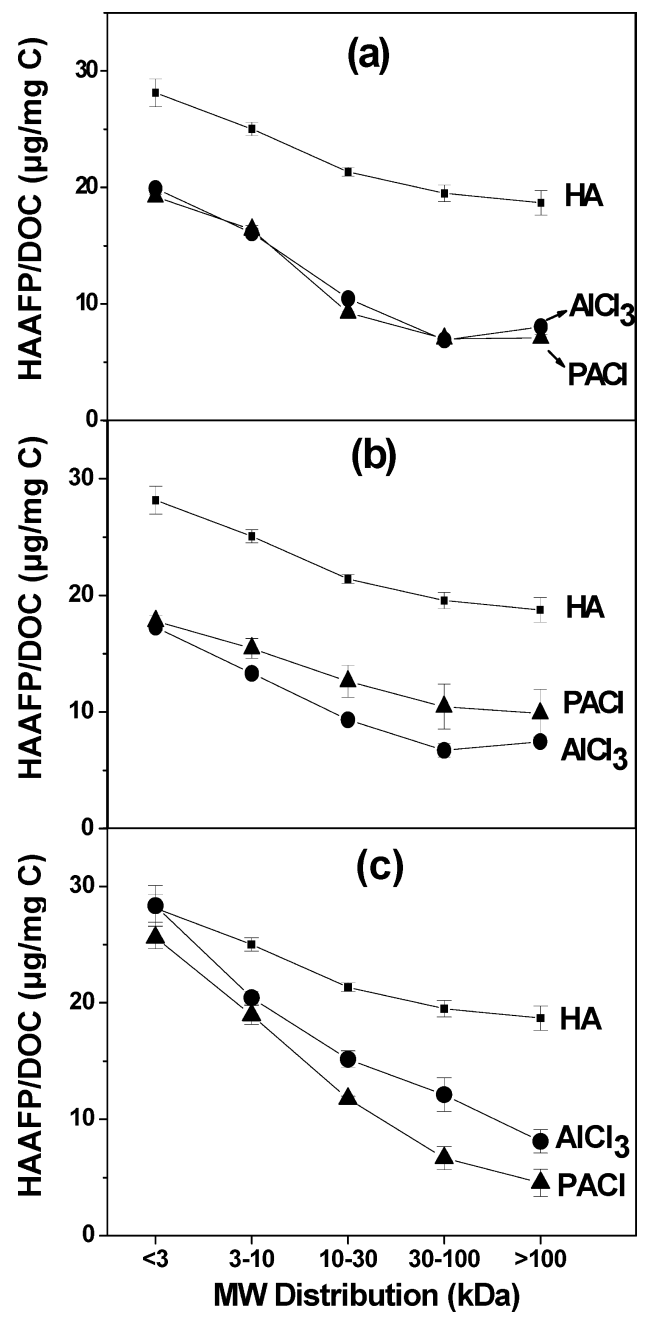

FIGURE 2. Specific HAAFP yields of different MW fractions after coagulation with $\mathrm{AICl}_{3}$ and $\mathrm{PACl}$ (coagulants dose: $0.8 \mathrm{mg}$ Al/mg DOC): (a) pH 3.5, (b) pH 5.5, and (c) pH 7.5.

As shown in Figure 2, specific HAAFP yields of HA fractions after coagulation were different from the specific THMFP yields. The ability of $\mathrm{AlCl}_{3}$ and $\mathrm{PACl}$ to remove HAA precursors over a wide $\mathrm{pH}$ range can be classified as three conditions. At $\mathrm{pH}$ 5.5, $\mathrm{AlCl}_{3}$ removed more HAA precursors than PACl, whereas $\mathrm{PACl}$ removed more HAA precursors than $\mathrm{AlCl}_{3}$ at $\mathrm{pH}$ 7.5. Specific HAAFP yields of $\mathrm{HA}$ fractions after $\mathrm{AlCl}_{3}$ and $\mathrm{PACl}$ coagulation were almost the same at $\mathrm{pH}$ 3.5.

The greatest removal of the HAA precursors by coagulation with $\mathrm{AlCl}_{3}$ and $\mathrm{PACl}$ can be divided into two sections. In the low MW fractions $(<30 \mathrm{kDa})$, the greatest removal of specific $\mathrm{HAAFP}$ yields by coagulation was with $\mathrm{AlCl}_{3}$ at $\mathrm{pH}$ 5.5. In the $<3,3-10$, and $10-30 \mathrm{kDa}$ fractions, the reductions of specific HAAFP yields by coagulation were $10.9,11.8$, and $12.2 \mu \mathrm{g} / \mathrm{mg}$ DOC, respectively. In the high MW fractions (>30 kDa), the greatest removal of HAA precursors by coagulation was with $\mathrm{PACl}$ at $\mathrm{pH}$ 7.5. In the $30-100$ and $>100 \mathrm{kDa}$ fractions, the reductions of specific HAAFP yields by coagulation with $\mathrm{PACl}$ were 13.4 and $14.1 \mu \mathrm{g} / \mathrm{mg}$ DOC, respectively. Furthermore, the high MW HAA precursors were removed more than the low MW HAA precursors by Al salt coagulation at $\mathrm{pH} 3.5$ and 7.5. The differences of HAA precursors in different MW fractions removed by coagulation were not significant at $\mathrm{pH}$ 5.5 .

Aluminum Speciation of Coagulants. Initial aluminum speciation of coagulants at high concentrations can be detected by ${ }^{27} \mathrm{Al}$ NMR spectroscopy, but aluminum speciation at low concentrations during coagulation processes is hard to detect. Previous studies (19) indicated that some hydroxyl aluminum polymers cannot be detected by current NMR spectroscopy but can react with Ferron. Our previous investigations (11) demonstrated aluminum speciation transformation of $\mathrm{AlCl}_{3}$ and $\mathrm{PACl}$ coagulants using an $\mathrm{Al}$-Ferron assay. On one hand, the $\mathrm{pH}$ significantly affected aluminum species distributions during the $\mathrm{AlCl}_{3}$ coagulation process. At pH 5.0-6.0, at least $80 \%$ of the monomers in the initial $\mathrm{AlCl}_{3}$ transformed into polymers. On the other hand, in contrast to $\mathrm{AlCl}_{3}$, the preformed $\mathrm{K}-\mathrm{Al}_{13}$ polymers in $\mathrm{PACl}$ were quite stable throughout the whole coagulation process.

On the basis of our earlier investigations, we further proved the presence of polymeric aluminum species in $\mathrm{AlCl}_{3}$ at $\mathrm{pH}$ 5.5 during coagulation by positive ion ESI-MS in this study. The ESI-MS spectra of the $\mathrm{AlCl}_{3}$ solution $\left(1.5 \times 10^{-4} \mathrm{~mol} / \mathrm{L}\right)$ at pH 5.5 are shown in Figure 3a. The most intensive peaks were at $\mathrm{m} / z 337(100 \%)$ and $\mathrm{m} / z 328$ with $58 \%$ relative intensity. In addition, dimeric aluminum species $\left[\mathrm{Al}_{2} \mathrm{O}_{2}\right.$ $\left.(\mathrm{OH})\left(\mathrm{H}_{2} \mathrm{O}\right)_{0-3}\right]^{+}$at $m / z 103,121,139$, and 157 also exist. The series of polymers containing $\mathrm{Al}_{9}(m / z 226,235$, and 244), $\mathrm{Al}_{10}\left(m / z 265,274\right.$, and 283), $\mathrm{Al}_{11}$ or $\mathrm{Al}_{14}(m / z 358$ and 367), $\mathrm{Al}_{12}\left(\mathrm{~m} / z 373,379\right.$, and 385), and $\mathrm{Al}_{13}$ or $\mathrm{Al}_{10}(\mathrm{~m} / z 213,219$, 225 , and 346) cores were observed as well in the spectra at pH 5.5 .

Ions with the relatively strongest intensities at $\mathrm{m} / \mathrm{z} 337$ and 328 also were selected to be analyzed using the ESIMS/MS product ion scan. The spectra of the fragment ions at $m / z 337$ and 328 are shown in Figure 4. Ions at $m / z 337$ were found to produce a prominent product ion peak at $\mathrm{m} / z$ 328 (Figure 4a), while daughter ions at $m / z 328$ still dominated the fragments of the signals at $m / z 328$ (Figure 4b). Sarpola et al. (20) reported that the $\mathrm{Al}_{13}$ core was highly stable and to break its structure required very high collision energies $(75 \mathrm{eV})$. In this study, no matter parent or product, the ion at $m / z 328$ was stable at all times. Hence, the signal at $\mathrm{m} / z$ 328 was assigned to $\left[\mathrm{Al}_{13} \mathrm{O}_{18}(\mathrm{OH})\right]^{2+}$, while the signal at $\mathrm{m} / z$ 337 was assigned to $\left[\mathrm{Al}_{13} \mathrm{O}_{17}(\mathrm{OH})_{3}\right]^{2+}$. Through changing two hydroxo groups to a oxo group, the parent ion $\left[\mathrm{Al}_{13} \mathrm{O}_{17}(\mathrm{OH})_{3}\right]^{2+}$ lost one water to form $\left[\mathrm{Al}_{13} \mathrm{O}_{18}(\mathrm{OH})\right]^{2+}$. This is consistent with previous literature (20). In addition, the signals both at $\mathrm{m} / \mathrm{z}$ 337 and at $\mathrm{m} / z 328$ were most likely overlapping signals. Other product ions of signals at $m / z 337$ and 328 (e.g., fragments at $m / z 298,301,329$, and $m / z 611$ ) also were observed in the MS/MS spectra. As shown in Table 2, other possible fragment ions at $\mathrm{m} / z 337$ and 328 may be $\left[\mathrm{Al}_{10} \mathrm{O}_{5}(\mathrm{OH})_{17} \mathrm{Cl}\right]^{2+}$ and $\left[\mathrm{Al}_{10} \mathrm{O}_{6}(\mathrm{OH})_{15} \mathrm{Cl}\right]^{2+}$, respectively. $\left[\mathrm{Al}_{10} \mathrm{O}_{5}(\mathrm{OH})_{17} \mathrm{Cl}\right]^{2+}$ may lose one hydrochloric acid and two water molecules to eliminate the chloride ligand, and then the ion at $m / z 301$ was produced. This compares favorably with the results of Sarpola et al. $(18,20)$, who indicated that chloride ligands were eliminated as easily as hydrochloric acid with relatively low collision energies. Additionally, aluminum may be removed from the cores along with chloro ligands when three $\mathrm{Al}_{10}$ were combined, and then the ion at $\mathrm{m} / z 329$ was produced. $\left[\mathrm{Al}_{10} \mathrm{O}_{6}(\mathrm{OH})_{15} \mathrm{Cl}\right]^{2+}$ may lose the aqua ligand and produce an ion at $\mathrm{m} / z$ 319. Similar to $\left[\mathrm{Al}_{10} \mathrm{O}_{5}(\mathrm{OH})_{17} \mathrm{Cl}\right]^{2+}$, aluminum may be removed from the cores along with chloro ligands when one (two or three) $\mathrm{Al}_{10}$ is combined together, and then the ion at $\mathrm{m} / z 298(\mathrm{~m} / z 329$ or 611) was produced. These findings indicate that the $\mathrm{Al}_{10}$ species may be metastable and transient, and thus, the $\mathrm{Al}_{10}$ core can break easily with the loss of a chloro ligand.

When the $\mathrm{pH}$ was raised to 7.5, amorphous flocs of $\mathrm{Al}(\mathrm{OH})_{3}$ formed in a short time, and the total ions largely decreased. This is consistent with the results of Rämö et al. (21). As shown in Figure 3b, $\left[\mathrm{Al}_{13} \mathrm{O}_{17}(\mathrm{OH})_{3}\right]^{2+}$ at $\mathrm{m} / z 337$ and $\left[\mathrm{Al}_{13} \mathrm{O}_{18}(\mathrm{OH})\right]^{2+}$ at $m / z 328$ were diminished, whereas dimeric $\left[\mathrm{Al}_{2} \mathrm{O}_{2}(\mathrm{OH})\left(\mathrm{H}_{2} \mathrm{O}\right)_{0-1}\right]^{+}$at $m / z 103$ and 121 was the dominating species in the spectrum. A very intense $\left[\mathrm{TMA}_{2} \mathrm{Cl}\right]^{+}$adduct signal at $m / z 183$ was observed at both $\mathrm{pH} 5.5$ and $\mathrm{pH}$ 7.5. According to a previous study (22), the presence of TMA 

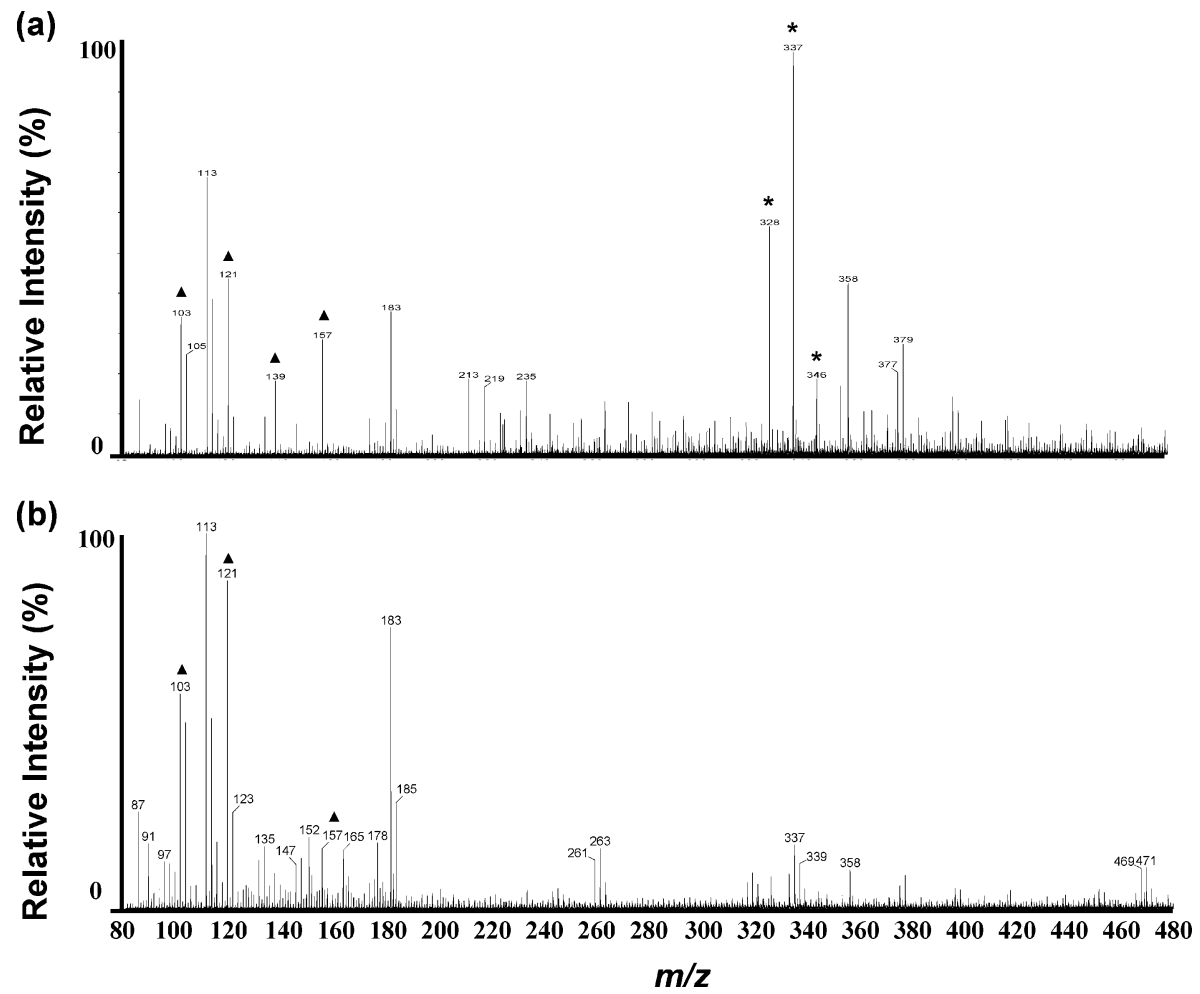

FIGURE 3. ESI-MS spectrum of $\mathrm{AICl}_{3}\left(1.5 \times 10^{-4} \mathrm{~mol} \mathrm{Al} / \mathrm{L}\right)$ : (a) pH 5.5 and (b) pH 7.5 (A: $\mathrm{Al}_{2}$ species; *: $\mathrm{Al}_{13}$ species).
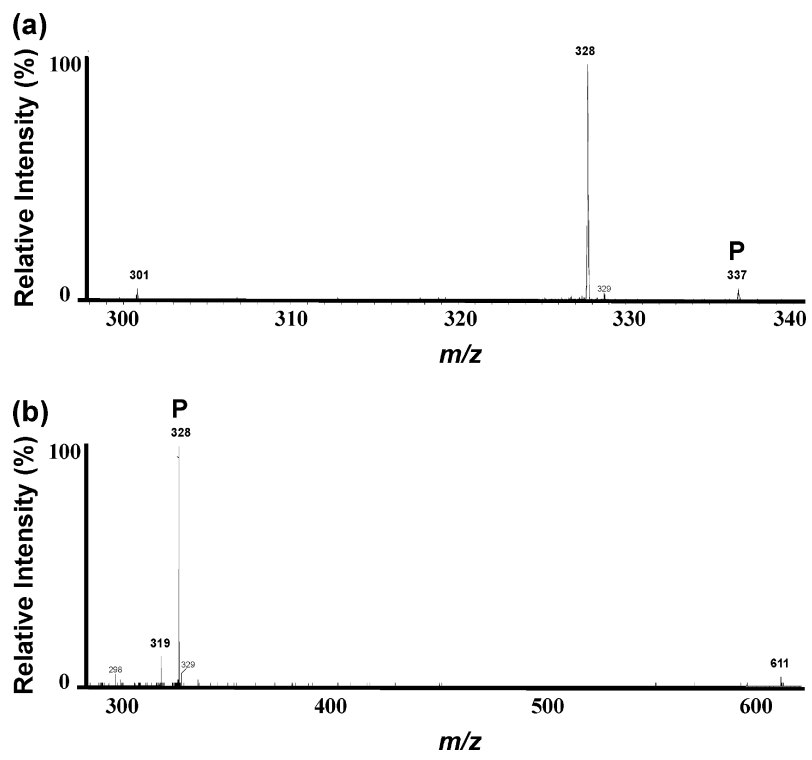

FIGURE 4. ESI-MS/MS spectrum of $\mathrm{AICl}_{3}$ at $\mathrm{pH} 5.5\left(1.5 \times 10^{-4}\right.$ mol Al/L): (a) $m / z 328$ and (b) $m / z 337$.

adducts also was observed in the samples due to $\mathrm{pH}$ adjustment by TMA. In this study, another very intense signal at $\mathrm{m} / z 113$ was observed as well; this may be assigned to $\left[\mathrm{K}_{2} \mathrm{Cl}\right]^{+}$. Potassium is an impurity that may originate from aluminum solutions. In addition, three distribution patterns of signals at $m / z 261-265,337-341$, and $469-473$ indicated the presence of chlorine isotopes in singly charged aluminum species. According to similar signals at $m / z 319-323$ that were $18 \mathrm{u}$ lower than the signals at $m / z 337-341$, the second series of signals may correspond to a singly charged $\mathrm{Al}_{5}$ complex with one aqua ligand. The first and third series of signals may be assigned to singly charged $\mathrm{Al}_{4}$ and $\mathrm{Al}_{6}$ complexes, respectively. However, the amount of chlorine was not easily determined without MS/MS results, and the
TABLE 2. Proposed Reactions Inferred from Figure 4a,b Fragment Ion Spectra of lons at $\mathrm{m} / \mathrm{z} 337$ and $328\left(\mathrm{AlCl}_{3}, 1.5\right.$ $\times 10^{-4} \mathrm{~mol} / \mathrm{L}$, pH 5.5)

$m / z$

Fragments at $\mathrm{m} / \mathrm{z} 337^{a}$ and possible fragmentation reactions

$301\left[\mathrm{Al}_{10} \mathrm{O}_{5}(\mathrm{OH})_{17} \mathrm{Cl}\right]^{2+}-\mathrm{HCl}-2 \mathrm{H}_{2} \mathrm{O} \rightarrow\left[\mathrm{Al}_{10} \mathrm{O}_{8}(\mathrm{OH})_{12}\right]^{2+}$

$328\left[\mathrm{Al}_{13} \mathrm{O}_{17}(\mathrm{OH})_{3}\right]^{2+}-\mathrm{H}_{2} \mathrm{O} \rightarrow\left[\mathrm{Al}_{13} \mathrm{O}_{18}(\mathrm{OH})\right]^{2+}$

$\left[\mathrm{Al}_{10} \mathrm{O}_{5}(\mathrm{OH})_{17} \mathrm{Cl}\right]^{2+}-\mathrm{H}_{2} \mathrm{O} \rightarrow\left[\mathrm{Al}_{10} \mathrm{O}_{6}(\mathrm{OH})_{15} \mathrm{Cl}\right]^{2+}$

$3292\left[\mathrm{Al}_{10} \mathrm{O}_{5}(\mathrm{OH})_{17} \mathrm{Cl}\right]^{2+}-\left[\mathrm{Al}_{3} \mathrm{O}_{3} \mathrm{Cl}_{2}\right]^{+}-9 \mathrm{H}_{2} \mathrm{O} \rightarrow$

$329\left[\mathrm{Al}_{17} \mathrm{O}_{16}(\mathrm{OH})_{16}\right]^{3+}$

$337 \quad\left[\mathrm{Al}_{13} \mathrm{O}_{17}(\mathrm{OH})_{3}\right]^{2+}$

$\left.337 \mathrm{Al}_{10} \mathrm{O}_{5}(\mathrm{OH})_{17} \mathrm{Cl}\right]^{2+}$

Fragments at $m / z 328^{b}$ and possible fragmentation reactions

$298\left[\mathrm{Al}_{10} \mathrm{O}_{6}(\mathrm{OH})_{15} \mathrm{Cl}\right]^{2+}-\mathrm{AlOCl}+\mathrm{H}_{2} \mathrm{O} \rightarrow\left[\mathrm{Al}_{9} \mathrm{O}_{4}(\mathrm{OH})_{17}\right]^{2+}$

$319\left[\mathrm{Al}_{10} \mathrm{O}_{6}(\mathrm{OH})_{15} \mathrm{Cl}\right]^{2+}-\mathrm{H}_{2} \mathrm{O} \rightarrow\left[\mathrm{Al}_{10} \mathrm{O}_{7}(\mathrm{OH})_{13} \mathrm{Cl}\right]^{2+}$

$328\left[\mathrm{Al}_{13} \mathrm{O}_{18}(\mathrm{OH})\right]^{2+}$

$328 \quad\left[\mathrm{Al}_{10} \mathrm{O}_{6}(\mathrm{OH})_{15} \mathrm{Cl}\right]^{2+}$

$3292\left[\mathrm{Al}_{10} \mathrm{O}_{6}(\mathrm{OH})_{15} \mathrm{Cl}\right]^{2+}-\left[\mathrm{Al}_{3} \mathrm{O}_{3} \mathrm{Cl}_{2}\right]^{+}-7 \mathrm{H}_{2} \mathrm{O} \rightarrow$

$\left[\mathrm{Al}_{17} \mathrm{O}_{16}(\mathrm{OH})_{16}\right]^{3+}$

$6113\left[\mathrm{Al}_{10} \mathrm{O}_{6}(\mathrm{OH})_{15} \mathrm{Cl}\right]^{2+}-\mathrm{AlCl}_{3}-3 \mathrm{H}^{+} \rightarrow\left[\mathrm{Al}_{29} \mathrm{O}_{21}(\mathrm{OH})_{42}\right]^{3+}$

${ }^{a}$ Collision energy: $20 \mathrm{eV} .{ }^{b}$ Collision energy: 20 or $30 \mathrm{eV}$.

aluminum species with ambiguous distribution patterns were difficult to identify.

Accordingly, as a coagulant during coagulation, $\mathrm{AlCl}_{3}$ hydrolyzed to form dominating in situ $\mathrm{Al}_{13}$ at $\mathrm{pH}$ 5.5. (In situ $\mathrm{Al}_{13}$ was present in the ESI spectra with forms of $\left[\mathrm{Al}_{13}-\right.$ $\left.\mathrm{O}_{17}(\mathrm{OH})_{3}\right]^{2+}$ and $\left[\mathrm{Al}_{13} \mathrm{O}_{18}(\mathrm{OH})\right]^{2+}$.) When the $\mathrm{pH}$ was 7.5 , amorphous flocs of $\mathrm{Al}(\mathrm{OH})_{3}$ formed in a short time, and in situ $\mathrm{Al}_{13}$ decomposed to dimers and small polymers. In contrast to $\mathrm{AlCl}_{3}$, Rämö et al. demonstrated aluminum speciation variation of PACl (high and medium basicities) at different $\mathrm{pH}$ values using ESI-MS. At $\mathrm{pH}$ 5, preformed $\mathrm{Al}_{13}$, with an ability to combine one or two additional aluminum atoms, played an important role. With an increase of the $\mathrm{pH}$, $\mathrm{Al}(\mathrm{OH})_{3}(\mathrm{~s})$ increased and the total ions decreased, but the 
major detected species were the same $\mathrm{Al}_{13}$ (21). Through aluminum speciation variation of $\mathrm{PACl}$ indicated by ESI-MS results and our previous study using the Ferron method (11), the preformed $\mathrm{K}-\mathrm{Al}_{13}$ polymers $\left(\left[\mathrm{Al}_{13} \mathrm{O}_{4}(\mathrm{OH})_{24}\right]^{7+}\right)$ in $\mathrm{PACl}$ were quite stable throughout the whole coagulation process.

Role of Aluminum Speciation in Removal of DBP Precursors with Different MWs. There are two mechanisms proposed for HA removal by aluminum coagulants $(5,6)$ : charge neutralization precipitation and adsorption on amorphous metal hydroxide precipitates. Generally, charge neutralization occurs at low $\mathrm{pH}$ values (only soluble aluminum species present). Adsorption (sweep flocculation) means the appearance of bulk hydroxide precipitation at high $\mathrm{pH}$ values or at high coagulant doses. When soluble aluminum species and $\mathrm{Al}(\mathrm{OH})_{3}(\mathrm{~s})$ are present at the same time, a simultaneous precipitation reaction should be considered.

In the present study, the variation of aluminum speciation can affect relative coagulation mechanisms for DBP removal at different $\mathrm{pH}$ conditions. However, the role of aluminum speciation in THM and HAA precursor removal was different. Some investigations indicated that THM and HAA had different precursors $(23,24)$. In their results, aliphatic structures played a more important role in THM formation than HAA formation, while HAAs had more aromatic structures as their precursors than THMs. Because of the structure differences between THM and HAA precursors, the THM and HAA precursor removal by coagulation with aluminum salts was distinct in this study. As shown in Scheme la,b, the role of aluminum speciation in the removal of THM and HAA precursors, respectively, with different MWs is discussed in detail.

For THM precursors, aliphatic structures with many negative charges were removed easily by charge neutralization precipitation. Preformed $\mathrm{K}-\mathrm{Al}_{13}$ of $\mathrm{PACl}$ removed more THM precursors than in situ formed $\mathrm{Al}_{13}$ of $\mathrm{AlCl}_{3}$ by charge neutralization at $\mathrm{pH}$ 5.5. Because of the larger size of the $\mathrm{Al}_{13}$ species, the complexes formed in low MW fractions were precipitated as easily as in high MW fractions. Hence, the effect of MW on DBP precursor removal by a coagulation process with in situ $\mathrm{Al}_{13}$ species and preformed $\mathrm{K}-\mathrm{Al}_{13}$ species was not significant.

When soluble aluminum species and $\mathrm{Al}(\mathrm{OH})_{3}(\mathrm{~s})$ were present at the same time, a simultaneous precipitation reaction of charge neutralization and adsorption occurred. However, charge neutralization precipitation for aliphatic structures in the THM precursors was easier than the adsorption of those. On one hand, both the low MW THM precursors and the high MW precursors were precipitated by preformed $\mathrm{K}-\mathrm{Al}_{13}$ of $\mathrm{PACl}$ through charge neutralization and adsorption. Thus, the effect of MW on THM precursor removal by $\mathrm{PACl}$ coagulation was not significant. On the other hand, more low MW THM precursors were precipitated than high MW precursors by dimeric aluminum species of $\mathrm{AlCl}_{3}$ through charge neutralization.

It was reported that negative charges on DBP precursors were partly neutralized by hydrogen ions in acidic conditions $(8,10)$. Because of electrostatic effects of DBP precursors decreasing, DBP precursors precipitated through self-aggregation and charge neutralization with aluminum species $(6,8)$. In this study, more THM precursors were neutralized by $\mathrm{PACl}$ with a higher $\mathrm{K}_{-} \mathrm{Al}_{13}$ content than $\mathrm{AlCl}_{3}$. Additionally, high MW THM precursors precipitated more easily through self-aggregation than low MW precursors.

The alkaline conditions of coagulation were not favorable for precipitate formation. Some researchers (25) indicated that hydrophilic acids showed a smaller adsorption affinity on preformed aluminum hydroxide flocs. Adsorption affinity also increased with an increase in SUVA of NOM. Aromatic carboxylates were adsorbed predominantly on aluminum hydroxide (26). In this study, the negatively charged flocs of
$\mathrm{Al}(\mathrm{OH})_{3}$ or $\mathrm{Al}(\mathrm{OH})_{4}{ }^{-}$ions (Hundt and O'Melia indicated that the $\mathrm{Al}(\mathrm{OH})_{3}(\mathrm{~s})$ precipitate decreased along with an increase of $\mathrm{pH}$; this is attributed to the presence of $\mathrm{Al}(\mathrm{OH})_{4}{ }^{-}$at high $\mathrm{pH}$ values (6)) were not effective on aliphatic structure removal through adsorption at $\mathrm{pH} 9.5$, particularly when the MW was low. Because of residual $\mathrm{K}-\mathrm{Al}_{13}, \mathrm{PACl}$ removed more THM precursors than $\mathrm{AlCl}_{3}$ by adsorption.

For HAA precursors, the removal of aromatic and hydrophobic structures through adsorption was easier than that through charge neutralization. Preformed $\mathrm{K}-\mathrm{Al}_{13}$ of $\mathrm{PACl}$ removed more HAA precursors than $\mathrm{AlCl}_{3}$ by adsorption at $\mathrm{pH}$ 7.5. Independently of the coagulation method applied, with $\mathrm{AlCl}_{3}$ or $\mathrm{PACl}$, high MW HAA precursors were precipitated by sweep flocculation more easily than low MW HAA precursors. In contrast, in situ formed $\mathrm{Al}_{13}$ of $\mathrm{AlCl}_{3}$ removed more HAA precursors than preformed $\mathrm{K}-\mathrm{Al}_{13}$ of $\mathrm{PACl}$ by charge neutralization at $\mathrm{pH}$ 5.5. Same as the THM precursors, the effect of MW on HAA precursor removal by a coagulation process with in situ $\mathrm{Al}_{13}$ species and preformed $\mathrm{K}-\mathrm{Al}_{13}$ species was not significant.

At acidic conditions, aromatic and hydrophobic structures with few negative charges were removed more through selfaggregation than charge neutralization. Thus, the ability of $\mathrm{AlCl}_{3}$ and $\mathrm{PACl}$ for removal of HAA precursors did not have significant differences. Besides, high MW HAA precursors precipitated more easily through self-aggregation than low MW ones. At alkaline conditions, aromatic and hydrophobic structures in the different MW fractions adsorbed on the flocs were removed by sweep flocculation. The effect of MW on HAA precursor removal by the coagulation process was not significant. The ability of $\mathrm{AlCl}_{3}$ and $\mathrm{PACl}$ of removing HAA precursors did not have significant differences.

Although DOC and $U_{254}$ have been widely used as indicators of DBPFP of NOM, the removal trends of DOC and $U_{254}$ (Table 1) were different from those of DBPFP in this study. Different from DBP precursors, the organic matter represented by DOC $\left(\mathrm{OM}_{\mathrm{DOC}}\right)$ and $\mathrm{UV}_{254}\left(\mathrm{OM}_{\mathrm{UV}}\right)$ had less fundamental groups with negative charges than DBP precursors, such as - $\mathrm{COOH}$ or -OH. Therefore, much less organic matter was removed through charge neutralization at $\mathrm{pH}$ 5.5, whereas much more organic matter precipitated through adsorption at $\mathrm{pH}$ 7.5. As compared to $\mathrm{OM}_{\mathrm{DOC}}, \mathrm{OM}_{\mathrm{UV}}$ had more fundamental groups with negative charges. Thus, more $\mathrm{OM}_{U v}$ was removed through charge neutralization at $\mathrm{pH}$ 5.5, while more $\mathrm{OM}_{\mathrm{DOC}}$ was removed through adsorption at $\mathrm{pH}$ 7.5 .

In summary, the role of aluminum speciation in the removal of DBP precursors by a coagulation process primarily depends on the following two factors. The first factor is related to in situ $\mathrm{Al}_{13}$ formed at $\mathrm{pH}$ 5.5. During coagulation, the in situ $\mathrm{Al}_{13}$ species of $\mathrm{AlCl}_{3}$ exhibited a better removal ability of HAA precursors than $\mathrm{PACl}$ at $\mathrm{pH}$ 5.5. The second factor was the characterization of DBP precursors. The in situ $\mathrm{Al}_{13}$ species did not have as high a removal ability of THM precursors as that of HAA precursors. PACl exhibited a better removal ability of THM precursors than $\mathrm{AlCl}_{3}$ at different $\mathrm{pH}$ conditions. Accordingly, as shown in Scheme 1c, the greatest reduction of HAA precursors with low MWs $(<30 \mathrm{kDa})$ was through charge neutralization at $\mathrm{pH} 5.5$, and that of HAA precursors in high MW ( $>30 \mathrm{kDa}$ ) fractions was through adsorption at $\mathrm{pH}$ 7.5. In the different MW fractions, the greatest reduction of THM precursors was through charge neutralization at $\mathrm{pH}$ 5.5. The present study supports the finding that aluminum speciation is useful in providing insight into the removal mechanisms of DBP precursors by coagulation and further demonstrates that ESI-MS measurements are a good method for aluminum speciation during coagulation. 
SCHEME 1. Schematic Diagram of Different MW DBP Precursor Removal by Different Aluminum Species ${ }^{a}$
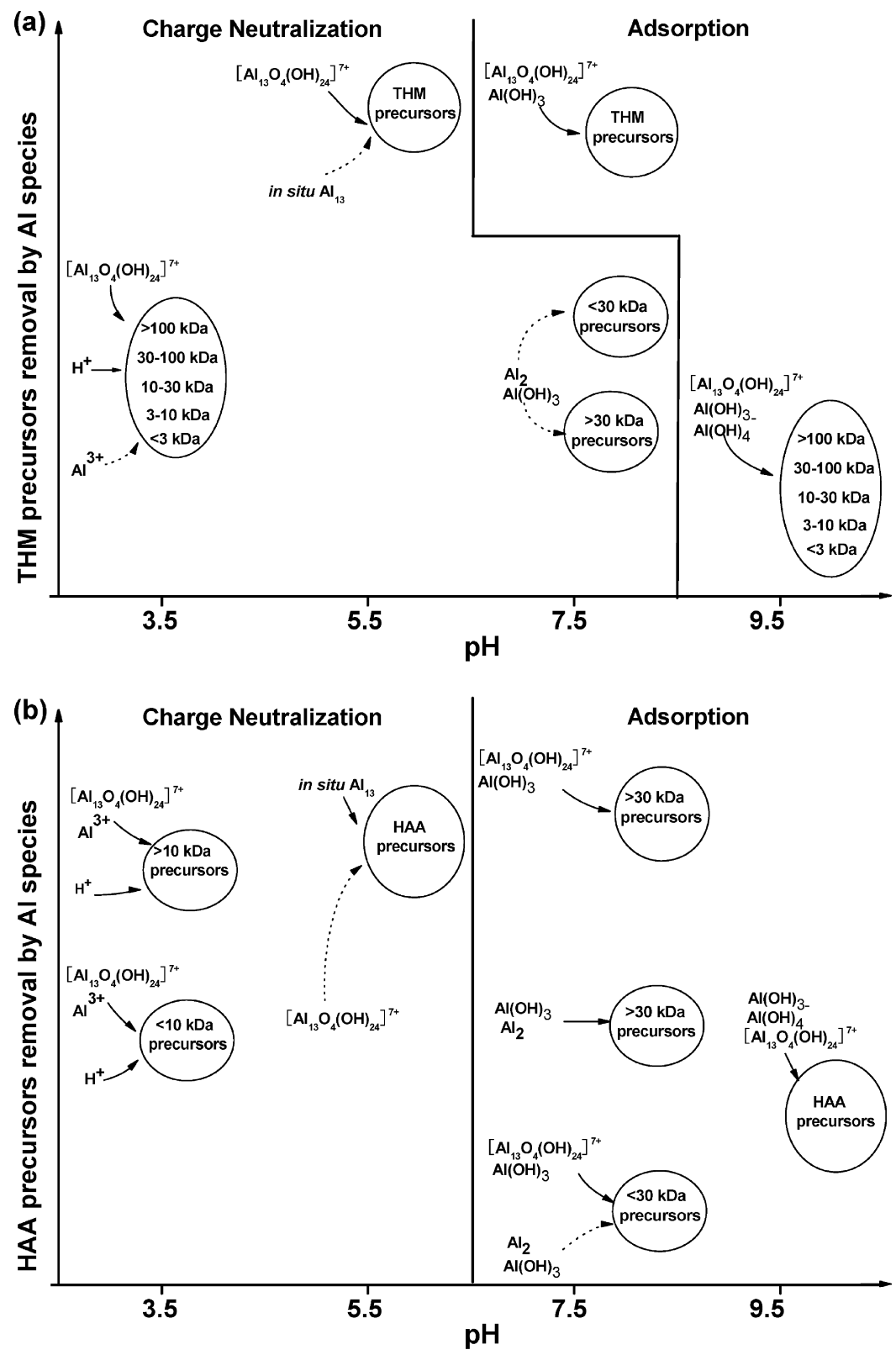

(c)

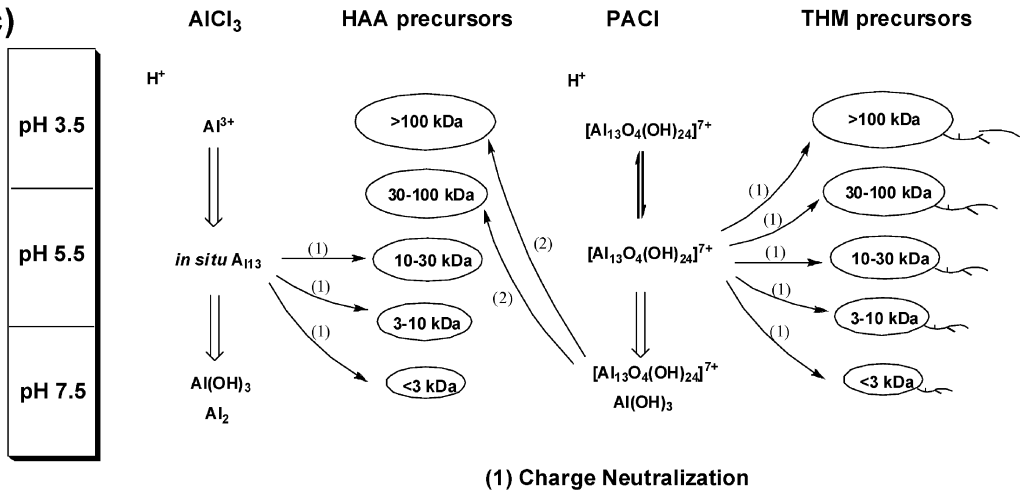

(2) Adsorption

a (a) Removal of THM precursors. (b) Removal of HAA precursors (reduction of DBP precursors by different aluminium species increased with the $Y$-axis, scale is arbitrary; circles of THM or HAA precursors with different MWs indicate corresponding removal of different MW DBP precursors; single THM or HAA precursors in circles indicate no differences of MW effect on DBP precursor removal; solid line represents the aluminum species having a higher removal ability of DBP precursors; dotted line represents the aluminum species having a lower removal ability of DBP precursors; charge neutralization and adsorption mechanisms of coagulation are separated by a bold solid line; and left section is charge neutralization, and right section is adsorption). (c) Greatest removal of DBP precursors. (To visually distinguish the structure of THM and HAA precursors, THM precursors have an aliphatic structure appended). 


\section{Acknowledgments}

This work was supported by the National Natural Science Foundation of China (Grants 20777087 and 50621804).

\section{Supporting Information Available}

Additional details of experimental methods. This material is available free of charge via the Internet at http:/ / pubs.acs.org.

\section{Literature Cited}

(1) Rook, J. J. Chlorination reactions of fulvic acids in natural waters. Environ. Sci. Technol. 1977, 11 (5), 478-482.

(2) Reckhow, D. A.; Singer, P. C.; Malcolm, R. L. Chlorination of humic materials: Byproduct formation and chemical interpretations. Environ. Sci. Technol. 1990, 24 (11), 1655-1664.

(3) Christman, R. F.; Norwood, D. L.; Millington, D. S.; Johnson, J. D.; Stevens, A. A. Identity and yields of major halogenated products of aquatic fulvic acid chlorination. Environ. Sci. Technol. 1983, 17 (10), 625-628.

(4) Reckhow, D. A.; Singer, P. C. The removal of organic halide precursors by preozonation and alum coagulation. J.-Am. Water Works Assoc. 1984, 76 (4), 151-157.

(5) Edzwald, J. K. Coagulation in drinking water treatment: Particles, organics, and coagulants. Water Sci. Technol. 1993, 27 (11), 2135.

(6) Hundt, T. R.; O'Melia, C. R. Aluminum-fulvic acid interactions: Mechanisms and applications. J.-Am. Water Works Assoc. 1988, 80 (4), 176-186.

(7) Tang, H. X.; Luan, Z. K. Features and mechanism for coagulation-flocculation processes of polyaluminum chloride. J. Environ. Sci. 1995, 7 (2), 204-211.

(8) Cheng, W. P. Comparison of hydrolysis/coagulation behavior of polymeric and monomeric iron coagulants in humic acid solution. Chemosphere 2002, 47 (9), 963-969.

(9) Casey, W. H. Large aqueous aluminum hydroxide molecules. Chem. Rev. 2006, 106 (1), 1-16.

(10) Shi., B. Y.; Wei, Q. S.; Wang, D. S.; Zhu, Z.; Tang, H.X. Coagulation of humic acid: The performance of preformed and nonpreformed Al species. Colloids Surf., A 2007, 296 (1-3), 141148.

(11) Hu, C. Z.; Liu, H. J.; Qu, J. H.; Wang, D. S.; Ru, J. Coagulation behavior of aluminum salts in eutrophic water: Significance of $\mathrm{Al}_{13}$ species and pH control. Environ. Sci. Technol. 2006, 40 (1), 325-331.

(12) Van Benschoten, J. E.; Edzwald, J. K. Chemical aspects of coagulation using aluminum salts: I. Hydrolytic reactions of alum and polyaluminum chloride. Water. Res. 1990, 24 (12), 1519-1526.
(13) Exall, K. N.; VanLoon, G. W. Effects of raw water conditions on solution-state aluminum speciation during coagulant dilution. Water Res. 2003, 37 (14), 3341-3350.

(14) Kitis, M.; Karanfil, T.; Wigton, A.; Kilduff, J. E. Probing reactivity of dissolved organic matter for disinfection byproduct formation using XAD-8 resin adsorption and ultrafiltration fractionation. Water Res. 2002, 36 (15), 3834-3848.

(15) American Public Health Association, American Water Works Association, Water Environment Association. Standard Methods for the Examination of Water and Wastewater, APHA: Washington, DC, 1998.

(16) U.S. EPA. Methods for the Determination of Organic Compounds in Drinking Water Supplement I; U.S. EPA: Cincinnati, OH, 1990.

(17) Lu, G. J.; Qu, J. H.; Tang, H. X. The electrochemical production of highly effective polyaluminum chloride. Water Res. 1999, 33 (3), 807-813.

(18) Sarpola, A. The Hydrolysis of Aluminum: A Mass Spectrometric Study. Ph.D. Thesis, University of Oulu, Oulu, Finland, 2007.

(19) Feng, C. H.; Tang, H. X.; Wang, D. S. Differentiation of hydroxylaluminum species at lower $\mathrm{OH} / \mathrm{Al}$ ratios by combination of ${ }^{27} \mathrm{Al}$ NMR and Ferron assay improved with kinetic resolution. Colloids Surf., A 2007, 305, 76-82.

(20) Sarpola, A.; Hietapelto, V.; Jalonen, J.; Jokela, J.; Laitinen, R. S.; Rämö, J. Identification and fragmentation of hydrolyzed aluminum species by electrospray ionization mass spectrometry. J. Mass Spectrom. 2004, 39, 1209-1218.

(21) Rämö, J. H.; Sarpola, A. T.; Hellman, A. H.; Leiviskä, T. A.; Hietapelto, V. K.; Jokela, J. T.; Laitinen, R. S. Colloidal surfaces and oligomeric species generated by water treatment chemicals. Chem. Speciation Bioavailability 2008, 20 (1), 13-22.

(22) Sarpola, A.; Hietapelto, V.; Jalonen, J.; Jokela, J.; Laitinen, R. S. Identification of the hydrolysis products of $\mathrm{AlCl}_{3} \cdot 6 \mathrm{H}_{2} \mathrm{O}$ by electrospray ionization mass spectrometry. J. Mass Spectrom. 2004, 39, 423-430.

(23) Liang, L.; Singer, P. C. Factors influencing the formation and relative distribution of haloacetic acids and trihalomethanes in drinking water. Environ. Sci. Technol. 2003, 37 (13), 2920-2928.

(24) Hua, G.; Reckhow, D. A. Characterization of disinfection byproduct precursors based on hydrophobicity and molecular size. Environ. Sci. Technol. 2007, 41 (9), 3309-3315.

(25) Bose, P.; Reckhow, D. A. The effect of ozonation on natural matter removal by alum coagulation. Water Res. 2007, 41 (7), $1516-1524$.

(26) Guan, X. H.; Chen, G. H.; Shang, C. Combining kinetic investigation with surface spectroscopic examination to study the role of aromatic carboxyl groups in NOM adsorption by aluminum hydroxide. J. Colloid Interface Sci. 2006, 301, 419-427. 